\title{
THE EFFECT OF TEACHING TECHNIQUES AND INTEREST ON STUDENTS' ACHIEVEMENT IN READING COMPREHENSION
}

\author{
BUSRI \\ Berlin Sibarani \\ Anni Holila Pulungan \\ Linguistik Terapan Bahasa Inggris Universitas Negeri Medan
}

Diterima Februari 2017; Disetujui April 2017; Dipublikasikan Juni 2017

\begin{abstract}
The objectives of this study were to find out whether students' achievement in reading comprehension taught by TELLS technique was significantly higher than PSOT. (2) whether the students' achievement in reading comprehension with high interest was higher than with low interest, and (3) If there was interaction between teaching techniques and interest on students' achievement in reading comprehension. This study established the different effect of teaching techniques on students' interest which was required by the hypothesis and applying experimental research design by using Factorial Design $2 \times 2$. Descriptive statistic was used to describe the data such as mean, median, mode, standard deviation, and variance. While inferential statistic used to test the research hypotheses by applying two ways ANOVA with the level of significance 0.05 . The results reveals that (1) students' achievement in reading expository text taught by using TELLS was higer than PSOT technique, with $\mathrm{F}_{\mathrm{ob}}=17.902>\mathrm{F}_{\mathrm{tab}}=3.11$, (2) students' achievement in reading expository text on hight interest was higher than that low interest, with $\mathrm{F}_{\mathrm{obs}}=38.988>\mathrm{F}_{\text {tab }}=3.11$, (3) there was interaction between teaching technique and interest on students' achievement in reading comprehension with $\mathrm{F}_{\mathrm{obs}}=5.962>\mathrm{F}_{\mathrm{tab}}=3.11$.
\end{abstract}

Keywords:Teaching Techniques, Interest, Reading Comprehension

How to Cite: Busri (2017).

The Effect of Teaching Techniques and Interest on Students' Achievement in Reading Comprehension, Jurnal Linguistik Terapan Pascasarjana Unimed., 14 (1):1-9 


\section{INTRODUCTION}

In Educational Unit Level Curriculum (Kurikulum Tingkat Satuan Pendidikan:TSP) students are expected to be competent in comprehending short functual text, dialogue, and monologue text in form of description, narration, procedure, recount, news item, report, exposition, spoof, review and explanation (Badan Stanard Nasional Pendidikan: BSNP, 2006).

Internationally, Loveless (2011) reported in the Brown Center on Education Policy that there are top ten countries and bottom ten countries in PISA 2009. Indonesia achieved the $14^{\text {th }}$ position of 22 countries with a score of 402 for reading comprehension and at 64th level of the 65 countries on PISA 2012. Hamra (2010) also found that Indonesian students difficult to understand the English texts although they are able to read fluently.

This fact was also supported by the observation results during two semester in academic year 2015 /2016 to the students at Eleventh grade of SMA Negeri 2 Rantau Utara Labuhanbatu which was applying educational unit level curriculum, the students' score was not as satisfactory as exspected in curriculum. They had difficulties in understanding the English text, partcularly analytical exposition text which was as learning material in grade eleventh. They did not achieve minimal completeness creterion (Kriteria Ketuntasan Minimai: KKM) score that 75 in English including their achievement in reading comprehension. It happens most students in eight paralel classes (science and social educational program).

Low of students' achievement in reading comprehension actually influenced by some factors. Alexander (1988) states, some factors that influence the reading comprehension comes from the students' own personality, reading materials and teachers personality. The other factor comes from the teachers personality. The teachers have low professional development, such as (1) lack of teaching inovation in using new teaching technique, (2) use inappropriate teaching techniques and medias, (3) teacher's book references, teachers frequently use the handout book and give reading exercise on it to the students and (4) reading is taught by the teacher throught traditional way which known as teacherscentered learning. This traditional approach often represents an exercise in one way communication that places the students in a passive role and which ultimately minimizes the students' ability to develope higher skills such analysis, evaluation and synthesis of idea and concepts. Reading passage will be difficult for students because they only get the knowledge from their teacher. Students do not actively involved in reading process, reading activity only covers reading the text and answer the questions provided that indivdually done by the students.

Consequently, students feel bored and do not interested with the materials in reading comprehension tasks. Therefore, their reading achievement is unsatisfying and hard for them to analize the text they read. 
To engage the students to be actively in the reading process and understand the text easily, teacher can pose TELLS techique which developed by Idol-Maestas (1985), Ridge \& Skinner, (2011). This technique was able to improve the students performance on comprehension questions and raised their scores on a standardized reading test.

TELLS stands for Title, Examine, Look, Look, and Setting. Each word is a sequential step that is used in the strategy process. The first step is title. Students are taught to look at the title of the selection and generate clues or guess what the material is going to be about. The second step is examine. students skim the passage and look for clues about the content. Third step look for, students are supposed to look for important words that may be repeated often. When students look again, they are looking for words that they do not know the meaning. The final step setting, students read the passage again and look for information related to setting. This can be places, dates, descriptions, or time periods. When using TELLS, students essentially read the passage at least three times, thus giving them a greater chance at comprehending the materials. This method is particularly useful when reading textbooks.

Another way to help students to monitor their comprehension was by using PSOT. PSOT is stand for Proposition Support Outlines Technique which developed by Buehl (1995). This technique helps students to learn to be critical readers who can recognize the differences of viewpoints, theories, hypotheses, and debatable assertions. Santa (1988) indicates that Proposition Support Outlines Techniques is an organizational technique that helps students select and evaluate information from a text, so that they can support an argument with evidence. Proposition Support Outlines Technique can improve critical tinking of the students and to find some supporting outlines and find some statements, such as fact,statistics, examples, expert authority and logic and reasoning.

Students' comprehension is most influenced by their interest, besides the teaching techniques were applied by teachers, interest of students are also determine the success of students in learning process. Interest is one of the psychological aspects that can encourage people achieve goals.According to Winkel, (1984) interest is the tendency to feel settled in the subject field or interest in certain things and feel happy working in that field.It means a person who has an interest in an object, tend to give attention or feel greater pleasure to those objects. However, if the object is not the cause of pleasure, the person will have no interest in the object. Therefore, the level of attention or object pleasure influences the interest level of a person.

Based on the explanation above, the researcher was intended in conducting a reseach on the effect of TELLS and PSOT techniques and interested on students' achievement in reading comprehension.

In relation to the background of the study, the research would like to know: (1) the students' achievement in reading comprehension taught by using Title, Examine, Look, Look, Setting (TELLS) technique and Proposition Support Outlines Technique (PSOT), (2) the students' achievement in reading comprehension with high interest and low interest (3) the interaction between teaching technique and 
interest on the students' achievement in reading comprehension.

\section{RESEARCH METHODOLOGY}

This study established the comparison (different effect of teaching techniques on students' interest) which was required by the hypothesis in this study. So this study carry out by applying experimental research design by using Factorial Design $2 \times 2$.

The population of this study were students of SMA Negeri 2 Rantau Utara Labuhanbatu. It is located on Jl. Menara No 4 Rantauprapat. The population was eleventh grade students in 2016 / 2017 School Year with sevent paralel classes, and 40 students administered for each class. So, the total number of the population in this study are 280 students. In this study, sample was chosen by using clutser random sampling technique. It was only two classes or 80 students who divided into two groups. The first group that consists of 40 students gave a treatment by using TELLS and the second group 40 students gave a treatment by using PSOT. From each group, assigned into 2 sub-groups high and low interest and each sub-group consists of 20 students.

Students' interest defined based on their interest questionnaires test scores that investigated by using likert scale form. Linkert Scale which presented a number of positive statements regarding an attitude object. Each statement consisted of four options, from the lowest to the highest statement.

In testing the students' achievement in reading comprehension, Multiple - choice technique was used by the researcher in consideration that it was an objective and common test used in reading comprehension.

To measure students' achievement in reading comprehension, the instrument in the form of reading comprehension test: reading short expository text administered. The type of reading comprehension test performed in this study was multiple choice with 40 items consist of eight reading expositorytexts genres. The test was arranged by using multiple choice test items with five options in each item such as a, b, c, d, or e. The correct answer got 1 score and 0 for wrong answer.

In analyzing the data, the researcher used descriptive statistic and inferential statistic technique. Descriptive statistic technique was used to describe the data such as mean, median, mode, standard deviation, and variance. Inferential statistic technique was used to test research hypotheses by applying two ways ANOVA (Analysis of Variance) with the level of significance 5\% or 0.05 .

Before two ways Anova was done, there were two requirements for the analysis; they are normality test by using Kolmogorov-Smirnov Test and homogeneity test by using F test and Barlett test through computer system called SPSS (Statistical Package for the Social Sciences).

After requirements for the analysis was done, there were interaction between both independent variables toward dependent variable based on the result of the F-observed analysis. Thus further test was done to verify the accurateness of finding out the effect of teaching techniques and interest on the students' achievement in reading comprehension. 


\section{FINDINGS AND DISCUSSIONS}

Based on data analysis and in line with the testing hypotheses, the research findings consist of three parts, they are:

1. TELLS and PSOT significantly affect students' achievement in reading expository text. It was found that students' achievement in reading expository text taught by using TELLS is higher than that taught by using PSOT. The result of data anaysis indicates that the mean score on students' achievement in reading expository text taught by using TELLS is 84.33 and the mean on students' achievement in reading expository taught by using PSOT is 78.65 (Figure 1). The result of data analysis by using two-way ANOVA test indicates that the $\mathrm{F}_{\mathrm{obs}}=17.902>\mathrm{F}_{\text {tab }}=3.11$ (manually) or $p$ $=0.000<0.05$ (SPSS). The result indicates that null hypothesis $(\mathrm{Ho})$ has been successfully rejected. Therefore, it can be concluded that the first research hypothesis which states students achievement in reading expository text taught by using TELLS is higher than that taught by using PSOT is really true in this research.

2. Students' interest significantly affects students' achievement in reading expository text. It was found that students' achievement in reading expository text of students with high interest is higher than that of students with low interest. The result of data analysis indicates that the mean score on students' achievement in reading expository text with high interest is 85.68 and the mean on students' achievement in reading expository with low interest is 77.13 (Figure 4.10). The result of data analysis with two-way ANOVA test indicates that the Fobs $=38.988>$ Ftab $=3.11$ (manually) or $\mathrm{p}=$ $0.000<0.05$ (SPSS). The result indicates that null hypothesis (Ho) has been successfully rejected. Therefore, it can be concluded that the second research hypothesis which states students' achievement in reading expository text of students with high interest is higher than that of students with low interest is really true in this research

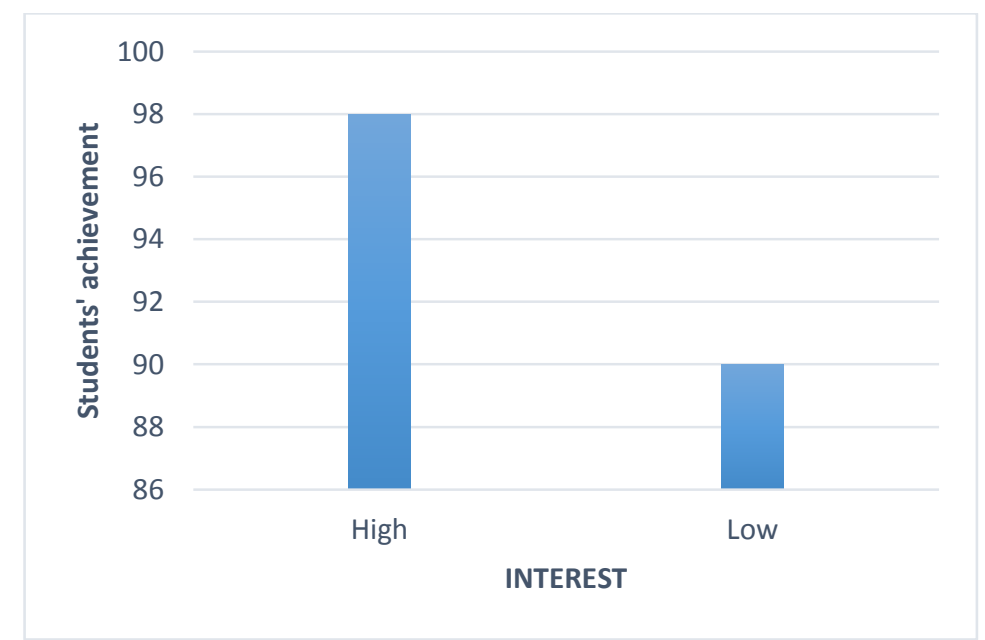

Figure 1. Students' Achievement in Reading Expository Text Taught 


\section{with High Interest is higher than that with Low Interest}

3. There is significant interaction between teaching techniques and interest on students' achievement in reading expository text. High interest students get higher achievement in reading expository text if they are taught by using TELLS. Meanwhile, low interest students get higher achievement in reading expository text if they are taught by using PSOT.

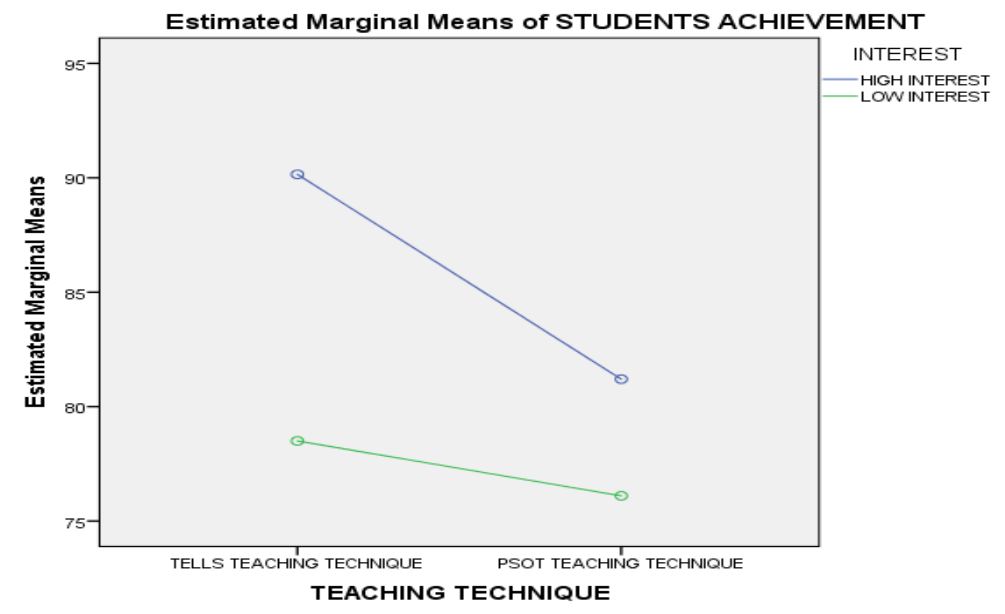

\section{Figure 2. Interaction between Teaching Techniques and Interest on Students' Achievement in Reading Expository Text}

Based on the findings that obtained from research hypotheses testing, it can be stated that:

a. Students' achievement in reading expository text taught by using TELLS is higher than that taught by using PSOT

There is difference between students' achievement in reading expository text that taught by TELLS and that taught by PSOT. The result of hypothesis shows that students' achievement in reading expository text that taught by using TELLS is higher than that taught by using PSOT. It is proven by the difference of students' mean score that gained from data calculation. Based on the data, the students' mean score taught by TELLS is 84.33 meanwhile students' mean score taught by PSOT is 78.68 . It means the mean score of students taught by TELLS exceeds the mean score of students taught by PSOT. The difference on the mean score of students taught by using TELLS and taught by PSOT was not too high as the theory hope because students were not familiar with this technique. They are just taught by using this technique for one time. Although the difference on the mean score of students taught by using TELLS and taught by PSOT was not too high, it could be said that students who taught by TELLS had higher achievement in reading than that of taught by PSOT.

The result was reasonable because TELLS allowed students interact with the text directly and got involved directly in the reading process. Students would get better achievement in reading expository text if they had opportunity to do reading in a plenty time. It is supported by Mc. Neil (1992)who states that the deeper a person processes text, the more he or she will remember and understand it. In TELLS, 
students do the reading process through reading many expository texts from many sources for example from scientific books, journals, magazines, newspaper articles or research report. The implementation of TELLS in teaching reading expository text is done through giving pre-questions as the starting point of the learning.

\section{b. Students' achievement in reading expository text of students with high interest is higher than that students with low interest}

The result of data analysis showed that students with high interest had different achievement in reading expository text to students with low interest. It was caused by students who had high interest had the ability in recognizing difficult words, and comprehending the information in the expository text that they read. They also had ability to analyze something. Ennis (1984) says that students with high interest will focus on deciding what to believe or what to do.

Students with high interest will think about what they are reading while they are reading it. Students who think critically routinely read texts that are significant and thus expand their worldview. When reading expository text, they consistently struggle to accurately represent in their own thinking what they are reading in the text.

The recognize that every text has a purpose, so they clarify the purpose of expository text that explains, exposes, or clarify one topic or an issue. They also recognize that close reading requires active engagement in reading, so they create an inner dialog with the text as they read such as questioning, summarizing, and connecting important ideas with other important ideas.

\section{c. The interaction between teaching techniques and interest on students' achievement in reading expository text}

Based on the research findings and hypotesis testing, there was significant interaction between teaching techniques and interest. Teaching techniques and students' interest were two important aspects that influence students' learning achievement.

TELLS as a teaching technique demand the students to be active in every stage of learning. In implementing TELLS in teaching reading, there some steps that should be followed. Some of them were analyzing, synthesizing, and evaluating the text. In the TELLS, students were presented with a situation that leads to a comprehending the text. When students were working in groups, analyzing complex words or sentences, and working together to find their meaning, they need high interest so that the discussion would be successfull.

TELLS was effective to be taught to students with high interest because the students had higher learning achievement in reading than it was taught to students with low interest. It was caused by students with high interest would be struggle in obtaining knowledge by searching relevant sources in order to solve problem presenting in TELLS. They more active, have good confidence, like to find a new idea, and make big effort to solve the problem. It is supported by Sternberg (1984) who states that interest is the ability to (1) identify the nature of a problem and decide on the processes necessary to 
solve the problem, (2) monitor and evaluate a problem-solving process, (3) make conclusions, (4) react effectively to new tasks and situation, and (5) process information effectively, which involves the ability to classify, compare, categories, analyze and evaluate. So, TELLS was effective taught to students with high interest. On the other hand, if the teacher applies TELLS to students with low interest, students would face difficulties in learning because low students with low interest are passive students who were lazy to think over to an issue. They only hope the information come from their teacher without doing any efforts to search needed information.

Meanwhile, PSOT technique was more effective if it was taught to students with low interest. Students with low interest did not have the ability of analyzing information needed to get solution for comprehending the text. In reading, they had no ability to evaluate deductive inferences, inductive inferences and the soundness of generalizations. They also had no ability to recognize hidden assumptions, to identify bias, and to recognize author's motives. Therefore, they are better taught by using PSOT.

\section{CONCLUSION}

Based on the research findings and discussions that are stated before, it can be concluded that (1) Students' achievement in reading expository text taught by using TELLS is higher than that taught by using PSOT. (2) Students' achievement in reading expository text of students with high interest is higher than that of students with low interest. (3) There is significant interaction between teaching techniques and interest on students' achievement in reading expository text. It can be said that students'achievement in reading expository text is influenced by teaching techniques and interest.

\section{SUGGESTIONS}

In connection with the conclusions and implications, there are some suggestions or recomendation

1. Teachers are recommended to use TELLS and PSOT in teaching reading since these two strategies can improve students' achievement in reading expository text.

2. Teachers are recommended to use TELLS for class which dominated by students with high interest. Otherwise for class which dominated by low interest students, teacher can use PSOT.

3. Teachers should consider the students' characteristics, especially students' interest in choosing teaching technique. It is hoped that teacher can guide students with low interest in order to get better achievement in reading expository.

\section{REFERENCES}

Alexander. J. E. (1988). Teaching Reading 3 Ed. Boston, Scott: Foresmen. 
Buehl, D. (2001). Classroom Strategies for Interactive Learning, Newark Del: International Reading Association.

Hamra \& Syatriana (2010), Developing A Model Of Teaching Reading Comprehension For Efl Students, TEFLIN Journal, Volume 21, Number 1, February 2010.

Idol-Maestas, L. (1985). Getting ready to read: Guided probing for poor comprehenders. Learning Disability Quarterly, 8, 243-254.

Loveless. T., (2011). How well are American Students Learning? With Sections on InternationalTests, Who's Winning the RealRace to the Top, and NAEP andthe Common Core State Standards. The Brown Center on Education Policy February 2011 Volume II, Number 5.

Ridge, A., \& Skinner, C., (2010). Using the TELLS Rereading Procedure to Enhance Comprehension Levels and Rates in Secondary Students. Psychology in the Schools, 48, 46-58.

Santa, C. M. (1988). Content Reading Including Study Systems. Dubuque, IA: Kendall-Hunt.

Seyler, Durothy U. (2004). The Reading Context: Developing College Reading Skill. New York: Pearson Educational. Inc.

Winkle.W.S. (1984). Psikologi Pendidikan dan evaluasi belajar, Jakarta, Gramedia. 